\title{
The subcellular distribution of copper, zinc and iron in liver and kidney. Changes during copper deficiency in the rat
}

\author{
By BEGOÑ ALFARO AND F. W. HEATON \\ Department of Biological Sciences, \\ University of Lancaster, Lancaster $L A_{1}{ }_{4} Y Q$ \\ (Received I6 fanuary 1974-Accepted 27 February 1974)
}

\begin{abstract}
I. The subcellular distribution of copper, zinc and iron was investigated in liver and kidney homogenates from $\mathrm{Cu}$-deficient and control rats. The supernatant fraction contained most $\mathrm{Cu}$ and $\mathrm{Zn}$ in control animals, but the highest proportion of $\mathrm{Fe}$ was in the microsomal fraction. 2. Cu deficiency reduced the concentration of the metal in all fractions, but the depletion was most severe and developed most rapidly in the supernatant fraction, indicating that the soluble cytoplasm is the site of $\mathrm{Cu}$ storage in the cell. The Fe content of the liver increased during $\mathrm{Cu}$ deficiency with $\mathrm{Fe}$ being deposited preferentially in the mitochondria.

3. All the $\mathrm{Cu}$ and most of the $\mathrm{Zn}$ in liver and kidney supernatant fractions occurred in four protein-containing fractions that were of similar molecular weights in both organs. A fraction of molecular weight 30000 was primarily concerned with $\mathrm{Cu}$ storage in mature rats.

4. The reduction in liver $\mathrm{Zn}$ during $\mathrm{Cu}$ deficiency appeared to be the result of impaired intestinal absorption and it is suggested that a small amount of $\mathrm{Cu}$ facilitates the absorption of $\mathrm{Zn}$.
\end{abstract}

The importance of the liver in providing a mobilizable reserve of copper that can be released to other tissues during $\mathrm{Cu}$ deficiency is well established (Dempsey, Cartwright \& Wintrobe, 1958; Dowdy, I969; Owen \& Orvis, 1970). Recent investigations in the rat showed that the kidney acts in a similar way, although to a lesser extent (Alfaro \& Heaton, I973), and also indicated that zinc and iron may accumulate in the liver during $\mathrm{Cu}$ deficiency.

This work has been developed by studying the changes occurring at the cellular level and the present paper reports the distribution of these metals among the main subcellular fractions of liver and kidney from $\mathrm{Cu}$-deficient and control rats. The supernatant fraction proved to be the true storage site for $\mathrm{Cu}$ and its association with proteins in the soluble part of the cell is considered.

\section{EXPERIMENTAL}

\section{Animals and diets}

Two groups of twenty-four weanling male Wistar albino rats weighing about $50 \mathrm{~g}$ were randomly selected and fed with $\mathrm{Cu}$-deficient $(0.4 \mathrm{mg} / \mathrm{kg} \mathrm{diet})$ and control (50 $\mathrm{mg} / \mathrm{kg} \mathrm{diet}$ ) diets for up to $126 \mathrm{~d}$. The animals were housed, three to a cage, in stainless-steel cages and all received an amount of food equal to that consumed by the least hungry cage of $\mathrm{Cu}$-deficient rats; this gave an initial intake of $7 \mathrm{~g}$ progressively rising to $\mathrm{I} 2 \mathrm{~g} / \mathrm{rat}$ per $\mathrm{d}$. Glass-distilled water that had been subsequently deionized was provided $a d$ lib. The cages were cleared with EDTA to remove traces of $\mathrm{Cu}$ and the synthetic diets were prepared by mixing $(\mathrm{g} / \mathrm{kg})$ : casein 200; sucrose 
660 ; arachis oil 80; cod-liver oil 20; salt mixture containing major minerals and trace elements 40; and purified vitamins, as described previously (Alfaro \& Heaton, 1973). The diets contained $12 \mathrm{mg} \mathrm{Zn/kg}$ and $180 \mathrm{mg} \mathrm{Fe} / \mathrm{kg}$, and were identical in composition except for their content of $\mathrm{Cu}$.

Equal numbers of rats from both groups were killed after various periods, each animal being taken from a different cage in the group. They were killed by cardiac puncture under diethyl ether anaesthesia, and heparinized plasma was separated immediately. Liver and kidneys were perfused through the aorta with $40 \mathrm{ml}$ of icecold isotonic medium before removal from the body. When tissues were required for cellular fractionation the medium was $0.25 \mathrm{M}$-sucrose, but when tissues were to be used for gel filtration, they were perfused with $0.075 \mathrm{M}$-potassium phosphate buffer, $\mathrm{pH} 7 \cdot 0$.

After 73 and $119 \mathrm{~d}$ on the diets some animals from both $\mathrm{Cu}$-deficient and control groups received $0.5 \mathrm{ml}$ of solution containing ${ }^{65} \mathrm{ZnCl}_{2}$ (The Radiochemical Centre, Amersham, Bucks.) by stomach-tube. On the first occasion four rats from each group, weighing about $190 \mathrm{~g}$, received $10 \mu \mathrm{Ci}$ per rat, and on the second occasion three different animals from each group, weighing about $35 \circ \mathrm{g}$, received $20 \mu \mathrm{Ci}$ per rat. The rats were fasted for $20 \mathrm{~h}$ before administration of the isotope and afterwards they were kept individually for $\mathrm{I}_{5} \mathrm{~d}$ in stainless-steel metabolism cages equipped with separators for urine and faeces to permit measurement of the urinary and faecal excretion of ${ }^{65} \mathrm{Zn}$.

\section{Cellular fractionation}

The liver and kidneys from each animal were homogenized with ice-cold $0.25 \mathrm{M}$ sucrose, using a Potter-Elvehjem homogenizer fitted with a Teflon pestle, to give $25 \%$ and $20 \%(\mathrm{w} / \mathrm{v})$ homogenates respectively. Differential centrifugation was carried out in duplicate to separate nuclear, mitochondrial, microsomal and supernatant fractions using the conditions adopted by Murdoch \& Heaton (I968), except that microsomes were sedimented by centrifuging at $105000 \mathrm{~g}$ for $60 \mathrm{~min}$. The composition of the particulate fractions was checked by electron microscopy. Recoveries of $\mathrm{Cu}$ and $\mathrm{Zn}$ from the four fractions were respectively $99 \cdot 2 \pm 4 \cdot 3 \%$ and $10 \mathrm{I} \cdot 3 \pm 2 \cdot 5 \%$ of the amounts in the original homogenate.

\section{Separation of supernatant-fraction proteins}

When proteins from the soluble part of the cytoplasm were required tissues were homogenized with an equal volume of $0.075 \mathrm{M}$-potassium phosphate buffer, $\mathrm{pH} 7 \cdot 0$, and the total homogenate was centrifuged for $60 \mathrm{~min}$ at $105000 \mathrm{~g}$. The supernatant fraction was removed and a measured volume ( $7 \mathrm{ml}$ liver, 2 ml kidney) subjected to gel filtration on Sephadex G-75 (Pharmacia, Uppsala, Sweden) using a procedure similar to that of Evans, Majors \& Cornatzer (1970). Separations were done at $4^{\circ}$ on $400 \times 25 \mathrm{~mm}$ columns and elution was carried out, at a flow rate of ro $\mathrm{ml} / \mathrm{h}$, with I mM-Tris buffer, $\mathrm{pH} 8.6$, which contained $0.05 \mathrm{M}-\mathrm{KCl}$. Fractions of I $\mathrm{ml}$ were collected and their extinction at $280 \mathrm{~nm}$ measured automatically. The void volume of the columns was determined with blue dextran and they were calibrated using 
four proteins of known molecular weight (Andrews, 1965 ). With careful standardization of the columns, the elution volume of any one protein varied by no more than $\pm \mathrm{I} \cdot 5 \mathrm{ml}$.

\section{Analytical methods}

Plasma was deproteinized with hydrochloric and trichloroacetic acids as described by Gubler, Lahey, Ashenbrucker, Cartwright \& Wintrobe (1952). The dry weight of subcellular fractions and tissue homogenates was measured after heating at $105^{\circ}$ for $\mathrm{I} 6 \mathrm{~h}$; with total homogenates and supernatant fractions allowance was made for the amount of sucrose present. Minerals were determined after wet ashing with a mixture of nitric and perchloric acids ( $5: 1$, by vol.). The perchloric acid was of Aristar quality, and all other reagents used in the separation and analysis of tissues were of Analar grade whenever possible.

$\mathrm{Cu}$ and $\mathrm{Zn}$ were determined in deproteinized plasma and solutions of tissue ash by atomic absorption spectrophotometry. Fe in tissue ash was also determined by atomic absorption analysis, but $\mathrm{Fe}$ in plasma was measured colorimetrically by the tripyridyl reaction, and the haemoglobin in blood was estimated as cyanmethaemoglobin (Dacie \& Lewis, 1963).

${ }^{65} \mathrm{Zn}$ was measured with a gamma counter (Nuclear Enterprises (GB) Ltd, Edinburgh). Urine, faeces and individual tissues were analysed in a well counter, and the activity of whole rats was determined by wrapping the animal in a polythene bag perforated at the end and placing it in an arm counter. Corrections were made for background readings and isotopic decay.

The statistical significance of differences was assessed by Student's $t$ test.

\section{RESULTS}

\section{Subcellular distribution of $\mathrm{Cu}, \mathrm{Zn}$ and $\mathrm{Fe}$}

Batches of six rats from each of the $\mathrm{Cu}$-deficient and control groups were killed after periods of 43 and $125 \mathrm{~d}$ on the diets, when the mean body-weights had increased to about $\mathrm{I} 80$ and $320 \mathrm{~g}$ in animals of both groups. The $\mathrm{Cu}$ concentrations in the plasma of the first and second batches of deficient rats were 0.30 and $0.16 \mu \mathrm{mol} / \mathrm{l}$ respectively, compared with values of $15.7-20.4 \mu \mathrm{mol} / 1$ in control animals, and the blood haemoglobin concentration was also lowered in both batches of deficient rats, but there was no significant difference in the concentrations of $\mathrm{Zn}$ or $\mathrm{Fe}$ in the plasma.

Considerable differences were observed between both the total amounts and the subcellular distribution of the three metals in the livers and kidneys of control rats (Table I). In both tissues the highest proportions of $\mathrm{Cu}$ and $\mathrm{Zn}$ usually occurred in the supernatant fraction, closely followed in liver by the nuclear fraction (Table 2), but the microsomal fraction always contained the largest amount of $\mathrm{Fe}$.

$\mathrm{Cu}$ deficiency greatly reduced the total amount of the metal in liver and kidney. This was the result of a lowered concentration in all subcellular fractions of liver from both batches of deficient rats and in all fractions of kidney from animals in the second deficient batch (Table $\mathrm{r}$ ). In animals of the first batch, which were less severely deficient after only $43 \mathrm{~d}$ on the diet, the supernatant fraction was the only kidney fraction with 


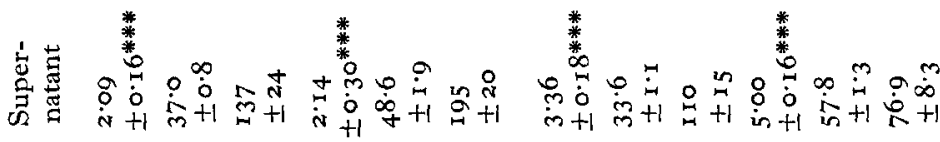

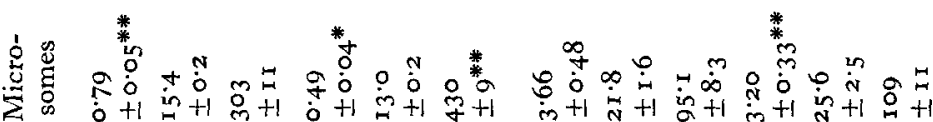

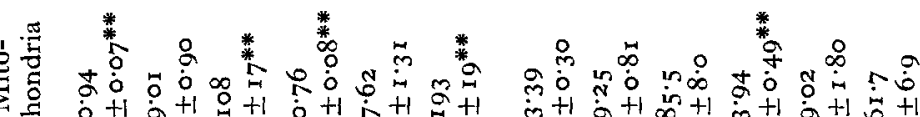

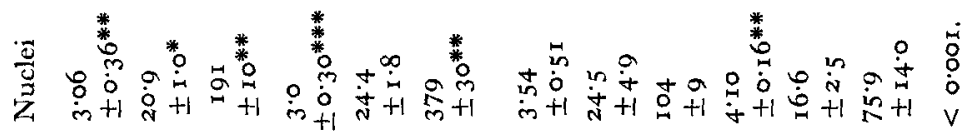

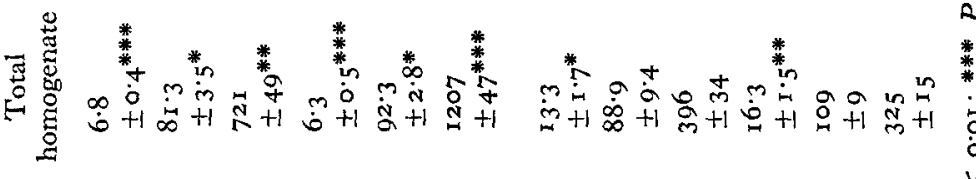

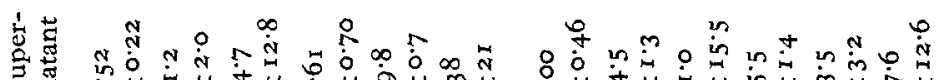

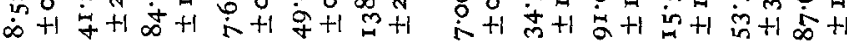

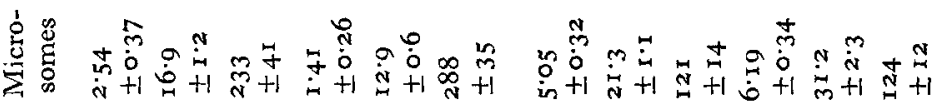

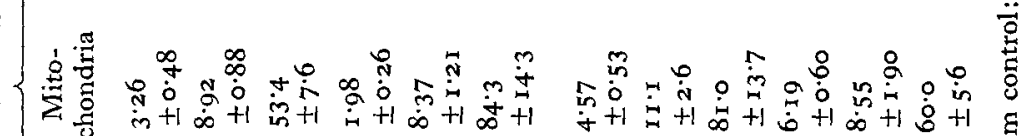

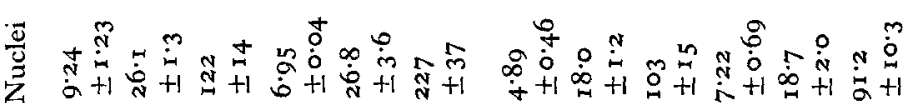
艺等+1

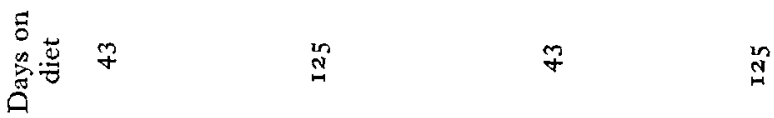

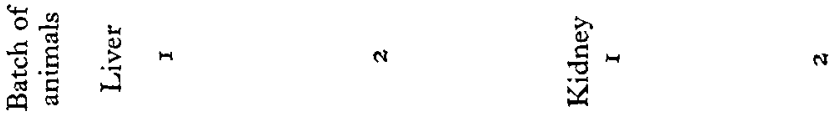


Vol. 32

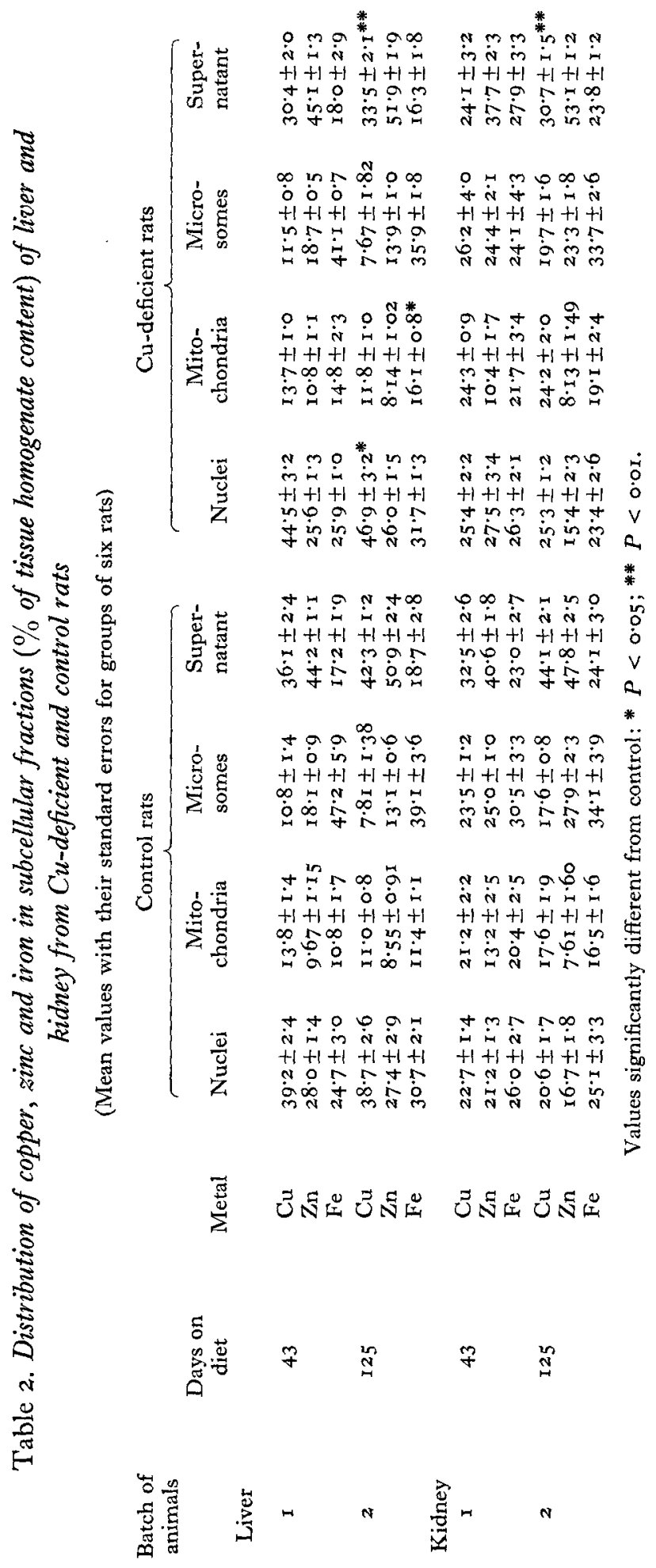




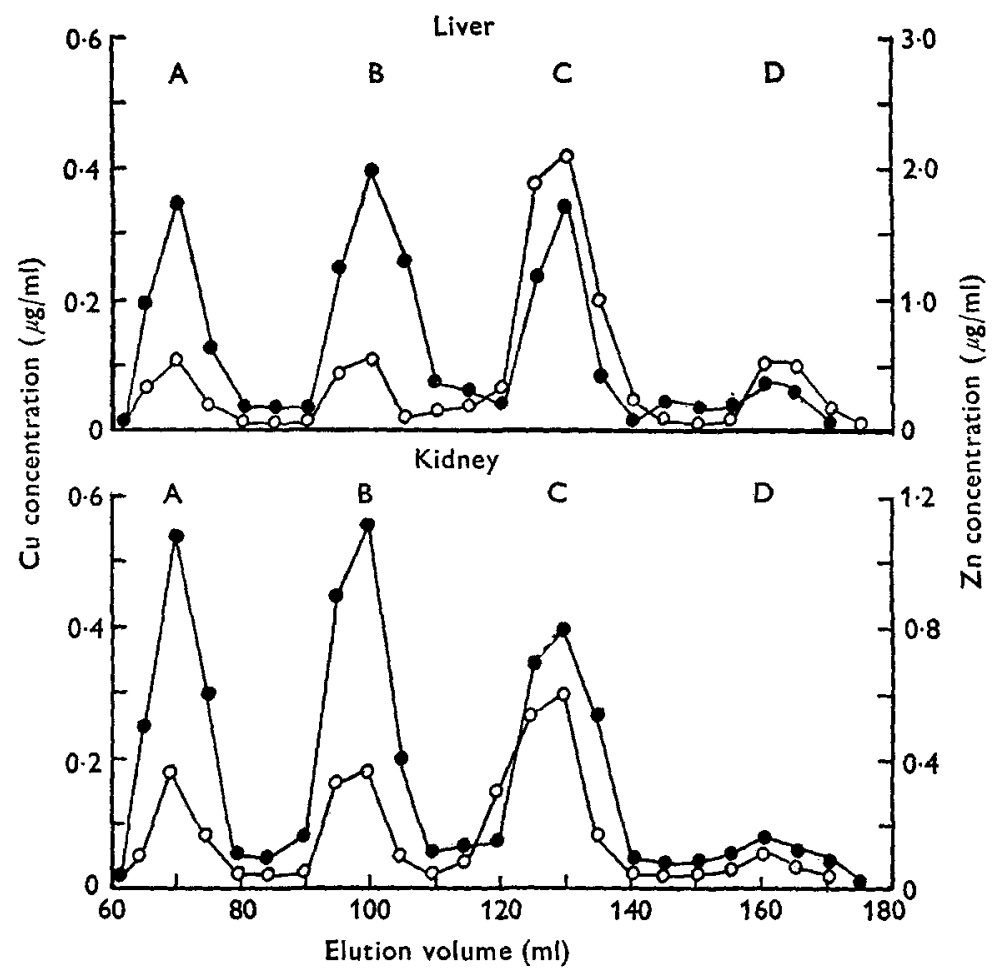

Fig. x. Separation of liver and kidney supernatant fractions on Sephadex G-75. The tissues were from the rats after $126 \mathrm{~d}$ on control diet. Concentrations of copper $(O)$ and zinc $(O)$ in fractions of $\mathrm{I} \mathrm{ml}$ are shown.

a statistically significant reduction in $\mathrm{Cu}$ concentration, suggesting that it was the site of initial depletion. Examination of the distribution of $\mathrm{Cu}$ within the cells of deficient rats (Table 2) indicates that the proportion present in the supernatant fraction of both liver and kidney was significantly reduced in the most severely deficient animals and the proportion in the nuclei tended to increase.

A secondary decrease in the concentration of $\mathrm{Zn}$ within the liver was observed in both batches of $\mathrm{Cu}$-deficient rats, but this appeared to be the result of a small loss from all fractions that caused no change in relative distribution of the metal. The amount of $\mathrm{Fe}$ in the liver increased markedly during $\mathrm{Cu}$ deficiency and this was the result of increased deposition in nuclear, mitochondrial and microsomal fractions, although the increase was proportionally most marked in the mitochondria. No changes in either the amount or the distribution of $\mathrm{Zn}$ and $\mathrm{Fe}$ in the kidney were observed during $\mathrm{Cu}$ deficiency.

\section{Association of $C u$ and $Z n$ with proteins in the supernatant fraction}

Four rats from each of the $\mathrm{Cu}$-deficient and control groups were killed $\mathrm{I} d$ later than the corresponding animals used for cellular fractionation. When the tissue supernatant fractions were subjected to gel filtration on Sephadex G-75, most of the $\mathrm{Cu}$ and 

$\dot{\rho}+1 \dot{m}_{+1} \dot{q}+1$ d

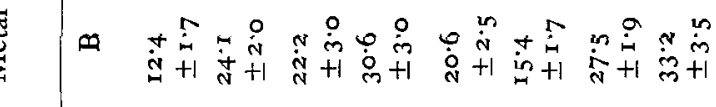

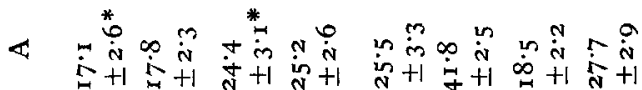

$\frac{\ddot{0}}{\tilde{\pi}}$

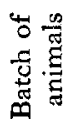

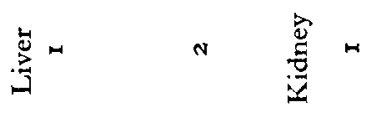


Table 4. Distribution of orally administered ${ }^{65} \mathrm{Zn}$ in copper-deficient and control rats after various periods on diet

(Mean values with their standard errors for four rats/group at $73 \mathrm{~d}$ and three/group at II9 $\mathrm{d}$ )

\begin{tabular}{|c|c|c|c|c|}
\hline \multirow[b]{3}{*}{ Location of isotope } & \multicolumn{4}{|c|}{ Recovery of ${ }^{65} \mathrm{Zn}$ as $\%$ of dose administered } \\
\hline & \multicolumn{2}{|c|}{$73 \mathrm{~d}$ on diet } & \multicolumn{2}{|c|}{ I I9 d on diet } \\
\hline & Control & Cu-deficient & Control & Cu-deficient \\
\hline $\begin{array}{l}\text { Retained in body } \\
\text { after day I } 5\end{array}$ & $57 \cdot 3 \pm 2 \cdot 5$ & $59^{\circ} \pm 5.2$ & $57.7 \pm 3.0$ & $45^{\cdot 6} \pm 2 \cdot 5^{*}$ \\
\hline $\begin{array}{l}\text { Excreted in faeces: } \\
\text { days } \mathrm{x}-7 \\
\text { days } 8-\mathrm{I}_{5}\end{array}$ & $\begin{array}{l}37 \cdot 3 \pm 4 \cdot 4 \\
5 \cdot 30 \pm 0 \cdot 60\end{array}$ & $\begin{array}{l}34.9 \pm 5.0 \\
4.58 \pm 0.24\end{array}$ & $\begin{array}{l}37 \cdot 7 \pm 3 \cdot 5 \\
3 \cdot 57 \pm 0.43\end{array}$ & $\begin{array}{l}50.3 \pm 2.8^{*} \\
2.6 r \pm 0.16\end{array}$ \\
\hline $\begin{array}{l}\text { Excreted in urine: } \\
\text { days } I-7 \\
\text { days } 8-15\end{array}$ & $\begin{array}{l}0.68 \pm 0.06 \\
0.42 \pm 0.08\end{array}$ & $\begin{array}{l}0.79 \pm 0.09 \\
0.54 \pm 0.08\end{array}$ & $\begin{array}{l}0.67 \pm 0.07 \\
0.44 \pm 0.02\end{array}$ & $\begin{array}{l}0.80 \pm 0.10 \\
0.55 \pm 0.03\end{array}$ \\
\hline
\end{tabular}

$\mathrm{Zn}$ was eluted together in four main fractions (Fig. I). The positions of elution of the fractions were similar for material from both liver and kidney, and the metal-containing fractions, which have been designated A, B, C and D in order of their removal from the columns, absorbed radiation of wavelength $280 \mathrm{~nm}$, suggesting that the metals were associated with protein. From the calibration of the columns, fraction A contained material with a molecular weight in excess of 75000 , because it was only slightly retarded by the gel, and fractions $\mathrm{B}, \mathrm{C}$ and $\mathrm{D}$ corresponded to molecular weights of approximately 65000,30000 and 10000 respectively. These four fractions contained $99-$ Ior $\%$ of the $\mathrm{Cu}$ placed on the columns, but about ${ }_{15} \%$ of the $\mathrm{Zn}$ in both liver and kidney supernatant fraction was eluted much later in a $5^{\text {th }}$ fraction designated $E$. This also had strong extinction at $280 \mathrm{~nm}$, suggesting that the $\mathrm{Zn}$ was associated with peptides or other materials of lower molecular weight.

The distribution of $\mathrm{Cu}$ and $\mathrm{Zn}$ among these fractions appeared to vary with the maturity of the control rats. The proportions of $\mathrm{Cu}$ and $\mathrm{Zn}$ in the supernatant fraction associated with fraction D were significantly lower in the liver and kidneys of the second batch of control rats than in the first $(P<0.0 \mathrm{I})$. Conversely the proportion of $\mathrm{Cu}$ in fraction $\mathrm{C}$ and $\mathrm{Zn}$ in fraction $\mathrm{B}$ rose with increasing age $(P<0.05)$ in both tissues (Table 3 ).

The decreased concentration of $\mathrm{Cu}$ in the liver supernatant fraction of deficient animals was due to a reduction in all fractions when compared with control animals of the same age. The reduction was, however, proportionally most marked in fraction $\mathrm{C}$, which contained the major part of the supernatant-fraction $\mathrm{Cu}$ in mature rats, and least in fraction $A$, thus increasing the proportion of the metal in that fraction. Little difference was found in the distribution of $\mathrm{Cu}$ among the protein fractions of kidney, where the reduction in supernatant-fraction $\mathrm{Cu}$ concentration was less severe than in the liver. 


\section{Metabolism of $Z n$ during $C u$ deficiency}

$\mathrm{Cu}$ deficiency was found to reduce the concentration of $\mathrm{Zn}$ in the liver (Table $\mathrm{I}$ ) and the metabolism of a trace quantity of orally administered ${ }^{65} \mathrm{Zn}$ was therefore investigated at two intervals during the depletion period. Severely deficient rats given ${ }^{65} \mathrm{Zn}$ at $\mathrm{I} 19 \mathrm{~d}$ excreted significantly more ${ }^{65} \mathrm{Zn}$ in the faeces during the ist week after administration of the isotope and retained less in the body than did control animals (Table 4), but no such difference was observed at an earlier stage of deficiency. Measurements made on individual organs from the second batch of animals showed a reduced incorporation of isotope into the livers of $\mathrm{Cu}$-deficient rats, which was mainly due to a decrease in the proportion of ${ }^{65} \mathrm{Zn}$ present in the supernatant fraction.

\section{DISCUSSION}

The results of this investigation indicate that the main reserve of $\mathrm{Cu}$ in rat liver and kidney is located in the soluble part of the cell cytoplasm. The supernatant fraction of both tissues contained the highest proportion of $\mathrm{Cu}$ in control animals, in agreement with the findings of Edwards, Olson, Heggen \& Glenn ( 1961 ) in adult Wistar rats, and Cu deficiency caused proportionally the greatest reduction in concentration of the metal in this part of the cell (Table 2), indicating that the major loss occurred from here. Moreover, $\mathrm{Cu}$ depletion in the kidney occurred most rapidly in the supernatant fraction (Table I), which confirms it as the true site of $\mathrm{Cu}$ storage, and this conclusion is consistent with the findings of Gregoriadis \& Sourkes (1967) and Mills \& Mitchell (1971). It does appear, however, that the maturity of the animal and the strain of rat both affect the distribution of $\mathrm{Cu}$ within the cell (Gregoriadis \& Sourkes, I967; Evans, Myron, Cornatzer \& Cornatzer, I970; Hermann \& Kun, 1961).

All the $\mathrm{Cu}$ and most of the $\mathrm{Zn}$ in liver and kidney supernatant fraction was associated with four distinct protein-containing fractions that were of similar molecular weights in both organs (Fig. I). These fractions were probably not homogeneous, but fraction C, which had a molecular weight of approximately 30000 , appears to be analogous to cytocuprein, a $\mathrm{Cu}$ and $\mathrm{Zn}$ metalloprotein isolated from human liver, brain and erythrocytes by Carrico \& Deutsch (1969, 1970). Similarly fraction D, with a molecular weight of about 10000 , may contain metallothionein, which has been obtained in a highly purified form from equine and human renal cortex (Kägi \& Vallee, 196r; Pulido, Kägi \& Vallee, 1966). Evans \& Cornatzer (1970) also found $\mathrm{Cu}$ and $\mathrm{Zn}$ associated with a protein of similar molecular weight in rat liver, kidney and duodenum, but we are not aware of any metalloproteins that could correspond to fractions $A$ and $B$, which had molecular weights in excess of 75000 and about 65000 respectively, although Davies, Bremner \& Mills (1973) have recently reported $\mathrm{Zn}$ associated with a fraction of molecular weight 65000 in rat-liver supernatant fraction. Unfortunately the amounts of material available in the present study were insufficient to permit further investigation.

The distribution of $\mathrm{Cu}$ and $\mathrm{Zn}$ among these four fractions in control animals was rather different, and it also varied with the age of the rat. The largest proportion of 
supernatant-fraction $\mathrm{Cu}$ was associated with fraction $\mathrm{C}$ in both liver and kidney from the second batch of control animals, but $\mathrm{Zn}$ was fairly evenly distributed among fractions $\mathrm{A}, \mathrm{B}$ and $\mathrm{C}$, all of which contained more than fraction $\mathrm{E}$ (Table 3 ). In the younger animals of the first batch, however, fraction $D$ contained a significantly higher proportion of the $\mathrm{Cu}$ and $\mathrm{Zn}$ in both tissues. It is recognized that intracellular $\mathrm{Cu}$ undergoes some redistribution between mitochondria and cytoplasm during the maturation process (Gregoriadis \& Sourkes, I967; Evans, Myron et al. 1970; Porter, 1970), and the present observation suggests this is associated with changes in the protein-binding of $\mathrm{Cu}$ within the cytoplasm itself.

The decreased concentration of $\mathrm{Cu}$ in the liver supernatant fraction from severely deficient animals was due principally to a reduction in the metal associated with fraction C. This contained the major proportion of soluble $\mathrm{Cu}$ in the tissues of mature rats and it may therefore be the fraction primarily concerned with the storage of cellular $\mathrm{Cu}$ in adult animals.

Secondary effects of $\mathrm{Cu}$ deficiency on $\mathrm{Zn}$ and Fe metabolism were observed in the liver but not in the kidney. Cu deficiency caused the deposition of additional $\mathrm{Fe}$ in most liver fractions, but the accumulation was proportionally most marked in the mitochondria. Gregoriadis \& Sourkes ( 1967 ) found that $\mathrm{Cu}$ accumulated preferentially in the mitochondria and nuclei of Fe-deficient rats, and it therefore appears that the mitochondria are closely involved in the interaction of $\mathrm{Cu}$ and $\mathrm{Fe}$ metabolism.

The decreased concentration of $\mathrm{Zn}$ in the liver of $\mathrm{Cu}$ deficient rats appeared to be the result of an impaired intestinal absorption of the metal. The increased faecal excretion and decreased retention in the body of orally administered ${ }^{65} \mathrm{Zn}$ was welldefined in rats severely deficient in $\mathrm{Cu}$ (Table 4 ), although no difference was found at an earlier stage of depletion. Antagonism between $\mathrm{Cu}$ and $\mathrm{Zn}$, with a high intake of either metal inhibiting absorption of the other, is well established (Lee \& Matrone, 1969; Starcher, 1969; Van Campen, 1970), but the present observation suggests that a minimum level of $\mathrm{Cu}$ is necessary in the body to facilitate the absorption of $\mathrm{Zn}$. This hypothesis provides an explanation for several puzzling observations, such as the increase in liver $\mathrm{Zn}$ after giving $\mathrm{Cu}$ to pigs on a low-Cu diet (Suttle \& Mills, I966), and our previous finding (Alfaro \& Heaton, 1973) that rats on suboptimum intakes of $\mathrm{Cu}$ accumulate $\mathrm{Zn}$ in the liver when animals on a severely deficient intake do not.

\section{REFERENCES}

Alfaro, B. \& Heaton, F. W. (1973). Br. Y. Nutr. 29, 73.

Andrews, P. (I965). Biochem. $\mathcal{F} .96,595$.

Carrico, R. J. \& Deutsch, H. F. (r969). F. biol. Chem. 244, 6087.

Carrico, R. J. \& Deutsch, H. F. (I 970 ). $\mathcal{F}$. biol. Chem. 245, 723.

Dacie, J. V. \& Lewis, S. M. (I963). Practical Haematology 3 rd ed., pp. 36, 402. London: J. and A. Churchill.

Davies, N. T., Bremner, I. \& Mills, C. F. (I973). Biochem. Soc. Trans. I, 985.

Dempsey, H., Cartwright, G. E. \& Wintrobe, M. M. (1958). Proc. Soc. exp. Biol. Med. 98, 520. Dowdy, R. P. (r 969). Am. F. clin. Nutr. 22, 887.

Edwards, C., Olson, K. B., Heggen, G. \& Glenn, J. (I 96I). Proc. Soc. exp. Biol. Med. ro7, 94.

Evans, G. W. \& Cornatzer, W. E. (1970). Fedn Proc. Fedn. Am Socs exp. Biol. 29, 695 Abstr.

Evans, G. W., Majors, P. F. \& Cornatzer, W. E. (1970). Biochem. biophys. Res. Commutz. 40, 1142.

Evans, G. W., Myron, D. R., Cornatzer, N. F. \& Cornatzer, W. E. (I970). Am. Y. Physiol, 218, 298. 
Gregoriadis, G. \& Sourkes, T. L. (1967). Can. F. Biochem. 45, 1841.

Gubler, C. J., Lahey, M. E., Ashenbrucker, H., Cartwright, G. E. \& Wintrobe, M. M. (1952). $\mathcal{~}$. biol. Chem. r96, 209.

Hermann, G. E. \& Kun, E. (1961). Expl Cell Res. 22, 257.

Kägi, J. H. R. \& Vallee, B. L. (I96I). F. biol. Chem. 236, 2435.

Lee, D. Jr \& Matrone, G. (1969). Proc. Soc. exp. Biol. Med. r30, I I90.

Mills, C. F. \& Mitchell, R. L. (1971). Br. F. Nutr. 26, 1 17.

Murdoch, J. A. \& Heaton, F. W. (1968). Comp. Biochem. Physiol. 26, г21.

Owen, C. A. Jr \& Orvis, A. L. (1970). Am. F. Physiol. 218, 88.

Porter, H. (1970). In Trace Element Metabolism in Animals p. 237 [C. F. Mills, editor]. Edinburgh and London: E. and S. Livingstone.

Pulido, P., Kägi, J. H. R. \& Vallee, B. L. (1966). Biochemistry, Easton 5, 1768.

Starcher, B. C. (I969). F. Nutr. 97, 32 I.

Suttle, N. F. \& Mills, C. F. (I g66). Br. F. Nutr. 20, I 35.

Van Campen, D. (1970). In Trace Element Metabolism in Animals p. 287 [C. F. Mills, editor]. Edinburgh and London: E. and S. Livingstone. 